\title{
Nelumbo nucifera leaf extract mediated synthesis of silver nanoparticles and their antimicrobial properties against some human pathogens
}

\author{
G. Premanand ${ }^{1} \cdot$ N. Shanmugam ${ }^{1} \cdot$ N. Kannadasan ${ }^{1} \cdot$ K. Sathishkumar ${ }^{1}$ • \\ G. Viruthagiri ${ }^{1}$
}

Received: 4 March 2015/Accepted: 19 March 2015/Published online: 4 April 2015

(c) The Author(s) 2015. This article is published with open access at Springerlink.com

\begin{abstract}
In the present report, bio-reduction of silver nitrate into silver nanoparticles using the leaf extract of Nelumbo nucifera is explained. The synthesized nanoparticles exhibited surface Plasmon resonance at $410 \mathrm{~nm}$. The crystalline nature of the biosynthesized silver nanoparticles was confirmed from the X-ray diffraction pattern. The functional groups responsible for bio-reduction of silver nitrate into silver were analyzed by Fourier transform infrared spectroscopy and confirmed by X-ray photoelectron spectrum. Field emission transmission electron microscope micrographs showed the formation of well-separated silver nanoparticles of size in the range of $30-40 \mathrm{~nm}$. The result of dynamic light scattering also confirms the mono-dispersed silver nanoparticles with average size of $35 \mathrm{~nm}$. The synthesized nanoparticles exhibited excellent antibacterial activity against the Gram-positive bacteria $B$. subtilis.
\end{abstract}

Keywords Nelumbo nucifera - Bio-reduction - Silver nanoparticles $\cdot$ Surface plasmon resonance $\cdot$ Gram-positive

\section{Introduction}

Peculiar physical and chemical properties of materials in nanoscale gain the span of attention of major research groups compared to bulk of the same chemical composition. Therefore, fabrication of materials with novel applications can be made possible by controlling the morphology and size at nano scale. Among the nanomaterials, metal nanoparticles have

N. Shanmugam

quantumgosh@rediffmail.com

1 Department of Physics, Annamalai University, Annamalai Nagar, Chidambaram 608 002, Tamil Nadu, India many important applications in medicine and pharmacy. For instant, silver nanoparticles can be used in medicine to reduce infection in burn treatment, to prevent bacteria colonization on dental materials, stainless steel materials, to eliminate microorganisms on textile fabrics, and for water treatment (Panacek et al. 2006; Bo et al. 2009; Tomsic et al. 2008). Although, many chemical methods are available to reduce silver nitrate into silver nanoparticles, they expect toxic chemical and complicated procedures (Alarcon et al. 2012; Panácek et al. 2009; Prucek et al. 2011; Shanmugam et al. 2014). As an alternate, researchers are revealing their interest in the synthesis of metallic nanoparticles through green technology (Rastogi and Arunachalam 2011; Vijayakumar et al. 2011; Yilmaz et al. 2011; Guidelli et al. 2011; Kouvaris et al. 2012). Many researchers have reported the biosynthesis of metal nanoparticles by plant leaf extracts and their potential applications (Salem et al. 2014; Abdel-Aziz et al. 2014; Sulaiman et al. 2013; Prabhu et al. 2013). Nelumbo nucifera (Lotus), an aquatic plant with medicinal values, is seen in India and China. This species can be multiplied either by sexual (seeds) or asexual (rhizomes) reproduction. $N$. $n u$ cifera is reported to have antidiarrhoeal and antimicrobial properties. In the present work, the bio-reduction of $\mathrm{AgNO}_{3}$ into AgNPs from the broth of N. nucifera leaf is reported. Further, the antimicrobial activity of the synthesized silver nanoparticles has also been discussed against Gram-positive and Gram-negative bacteria.

\section{Materials and methods}

\section{Sample collection}

Fresh leaves of Nelumbo nucifera from the family of nelumbonaceae were collected from Natrajor temple pond 
$\left(11.3994^{\circ} \mathrm{N}, 7^{2} .6933^{\circ} \mathrm{E}\right)$ of Chidambaram, Tamil nadu, India.

\section{Materials}

Silver nitrate $\left(\mathrm{AgNO}_{3}\right)$ was purchased from Merck. The glass wares used in this experimental work were acid washed. Ultrapure water was used for all dilution and sample preparation.

\section{Preparation of the leaf extract}

Fresh and healthy leaves were collected and rinsed thoroughly first with tap water followed by distilled water to remove all the dust and unwanted visible particles, cut into small pieces, and dried at room temperature for 10 days. The dried leaves were made into powder using a kitchen blender. Broth of the Nelumbo nucifera was prepared by mixing $20 \mathrm{~g}$ of dried leaf powder with $100 \mathrm{~mL}$ of water and then boiled at $80{ }^{\circ} \mathrm{C}$ with constant stirring on a magnetic stirrer. The extracts were then filtered thrice through Whatman No. 1 filter paper with pore size in the range of 20-25 micron to remove particulate matter and stored in the Erlenmeyer flasks for further experiments. Throughout the experiment, sterility conditions were maintained for effectiveness and accuracy in results.

\section{Preparation of silver nanoparticles}

The $10 \mathrm{ml}$ of filtered extract was mixed with $90 \mathrm{ml}$ of $5 \mathrm{mM} \mathrm{AgNO}$ and incubated in the dark environment for $12 \mathrm{~h}$, and the control was also maintained without the addition of plant extract. The bio-reduction of $\mathrm{AgNO}_{3}$ into AgNPs can be confirmed visually by the change in color from colorless to reddish brown (Fig. 1).

\section{Characterization techniques}

Characterization of nanoparticles is important to understand and control nanoparticles synthesis and application. The formation of AgNPs was confirmed by sampling the reaction mixture at regular intervals and the absorption maximum was scanned by UV-Visible spectra, in a range of wavelength between 300 and $700 \mathrm{~nm}$ using LAMDA 25 PERKIN ELMER spectrometer. The X-ray diffraction (XRD) patterns of the silver nanoparticles were recorded using X'PERT PRO diffractometer with $\mathrm{Cu}-\mathrm{K} \alpha$ radiation $(\lambda=1.5406 \AA)$. The crystallite size was estimated using the Scherrer's equation. The metal state of AgNPs was examined using Thermo Fisher Scientific Inc., K-Alpha, USA, X-ray photoelectron spectroscopy (XPS) system. The presence of functional groups in leaf extract and

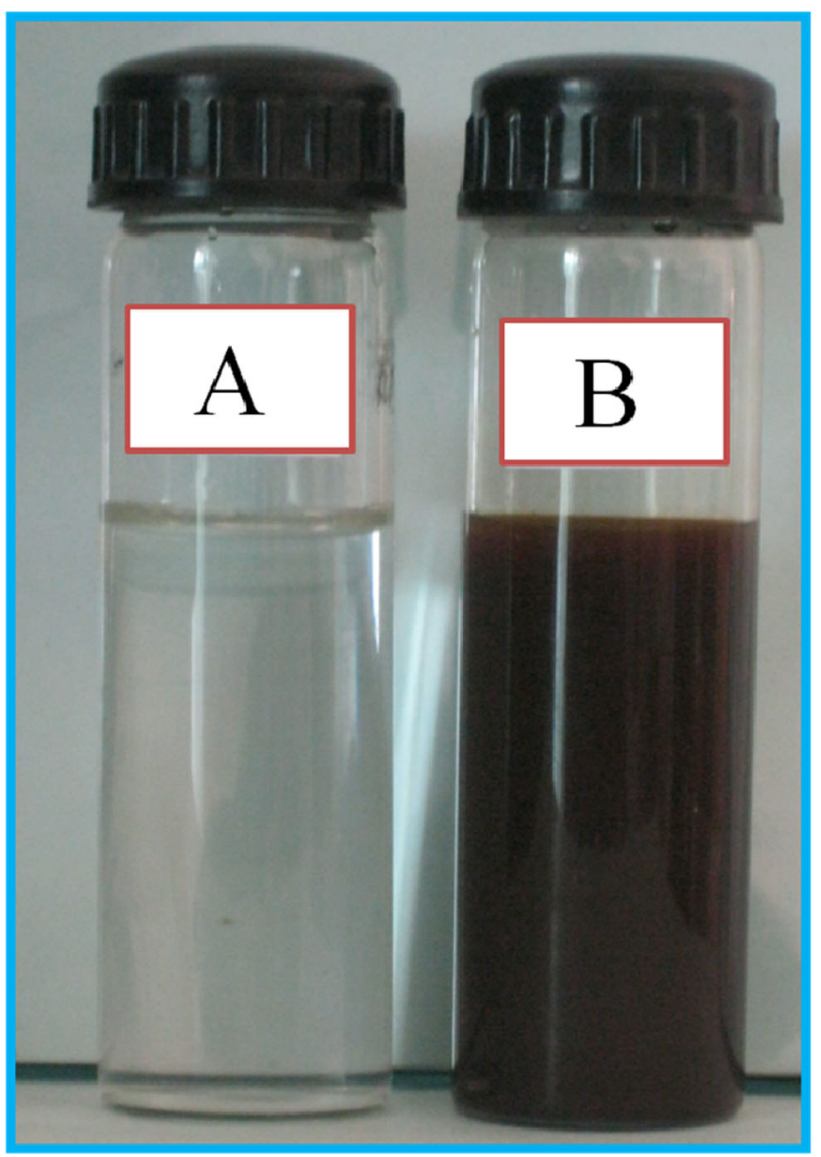

Fig. $1 a$ Silver nitrate $\left(\mathrm{AgNO}_{3}\right)$ solution and $b$ color change during the reduction of $\mathrm{AgNO}_{3}$ into AgNPs by the extract of $N$. nucifera after $120 \mathrm{~h}$ of incubation

synthesized AgNPs was identified by SHIMADZU-8400 FT-IR Spectrometer using $\mathrm{KBr}$ pellet technique. DLS measurements were carried out with a DLS particle size analyzer [ZETA Seizers Nanoseries (Malvern Instruments Nano ZS)] to estimate the average size distribution of the prepared particles. Field emission transmission electron microscopy (FE-TEM) analysis was performed (JSM 2100F JEOL) to study the morphology and size of the $\mathrm{Ag}$ nanoparticles.

\section{Antibacterial activity}

Silver is known for its antibacterial properties and has been used for years in the medical field for antimicrobial applications and even has shown to prevent HIV binding to host cells (Nino-Martinez et al. 2008; Alt et al. 2004; Russel and Hugo 1994; Lee et al. 2007; Jeong et al. 2005). In addition, silver has been used in water and air filters to eliminate microorganisms (Chou et al. 2005; Jin et al. 2007). In the present work, the synthesized Ag nanoparticles in aqueous were tested against bacterial pathogens by agar disc diffraction method (Karting et al. 1991). The 
pathogens namely Escherichia coli, Bacillus subtilis, Salmonella typhi, and Vibrio cholerae were obtained from Raja Sir Muthaiya Medical College, Annamalai University. About $150 \mathrm{CFU} / \mathrm{ml}$ of inoculums was swabbed onto $\mathrm{MH}$ agar plates uniformly and allowed to dry in a sterile environment. Sterile disc of $6 \mathrm{~mm}$ (HIMEDIA) was loaded with $30 \mu \mathrm{l}$ of test solution $\left(\mathrm{AgNO}_{3}\right.$ and $\mathrm{Ag}$ nanoparticles). Ampicillin (10 mg in $1 \mathrm{ml}$ ) was used as positive control. The plates were incubated at $25^{\circ} \mathrm{C}$ for 3 days to measure the zone of inhibition. The mean was calculated by performing the experiments in triplicates.

\section{Results and discussion}

\section{UV-Visible absorption spectra}

Bio-reduction of silver nitrate into silver nanoparticles in the presence of $N$. nucifera extract was confirmed from $\mathrm{UV}-\mathrm{V}$ is spectral measurements. AgNPs have free electrons, which have the probability to give rise to a surface Plasmon resonance (SPR) absorption band (Binupriya et al. 2010), due to the combined vibration of electrons of metal nanoparticles in resonance with the light wave. The UVVis absorption results of AgNPs with different time of incubation are shown in Fig. 2. As shown in figure, the broad spectrum of AgNPs with absorption maximum at $410 \mathrm{~nm}$ was seen due to the surface plasmon resonance. It is also noted that the increase in incubation time increases the reduction process and intense absorption has been

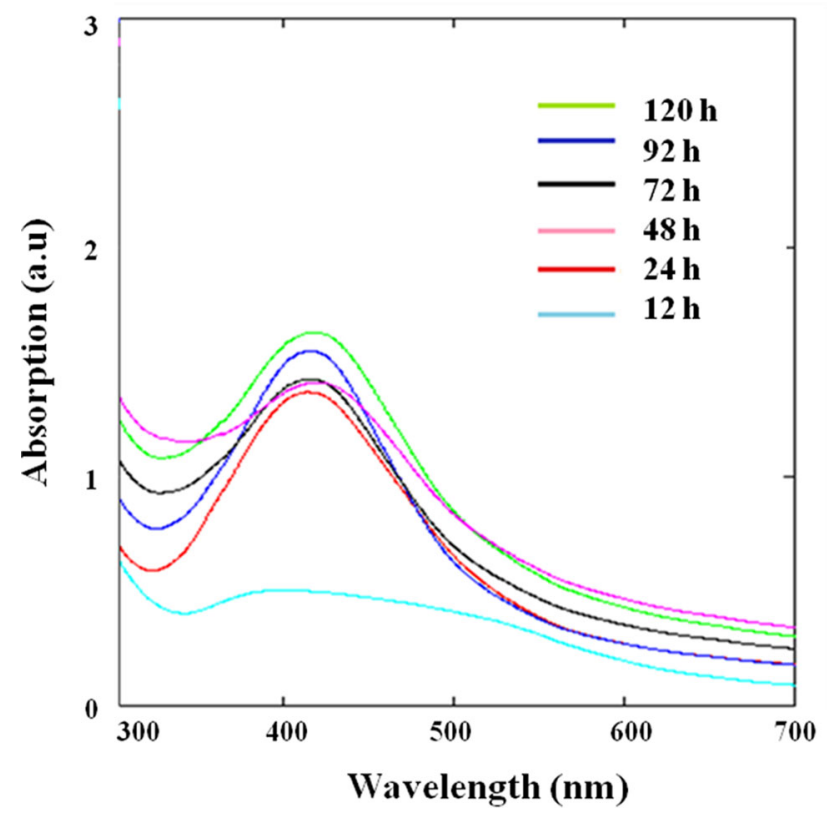

Fig. 2 UV-visible absorption spectra of silver nanoparticles with different incubation time predicted at $120 \mathrm{~h}$ of incubation. The presence of amides and methoxy groups in the extract of $N$. nucifera may play an important role in reduction and stability of AgNPs.

\section{Structural analysis}

Figure 3 depicts the X-ray diffraction pattern of silver nanoparticles prepared using Nelumbo nucifera leaves extract. The diffraction pattern has four main diffraction features corresponding (111), (200), (220), and (311) planes and all the four peaks can be indexed to standard cubic phase of silver (JCPDS card No: 04-0783) (Shanmugam et al. 2014). No reflection planes related to nitrate ions and other impurities were detected in the diffraction pattern, revealing the high purity of the synthesized product. Obviously, it is seen that the obtained reflections are sharp and high in intensity, indicating that the prepared silver nanoparticles are well crystalline in nature. Further, the lattice constant of the prepared cubic silver is found to be $a=4.085 \AA$, which is consistent with the JCPDS value ( $a=4.086 \AA$ ). The average crystalline size estimated from Debye-Scherrer's formula is around $25 \mathrm{~nm}$.

\section{XPS of the silver nanoparticles}

Figure 4 exhibits the XPS results of the obtained AgNPs. The overall spectrum indicates the presence of strong $\mathrm{C}$ $1 \mathrm{~s}, \mathrm{O} 1 \mathrm{~s}, \mathrm{~N} 1 \mathrm{~s}$, and Ag 3d core levels (Fig. 4a). The presence of carbon at $284.8 \mathrm{eV}$ corresponds to the carbon contribution from the phenyl rings of the protein (Jeona and Kang 2008). The N 1 s peak at $399.8 \mathrm{eV}$ could be assigned to neutral amine groups present in the protein moiety (Sharma et al. 2004). The O 1 s core level assigned at $532.1 \mathrm{eV}$ can be ascribed to the carboxylate groups

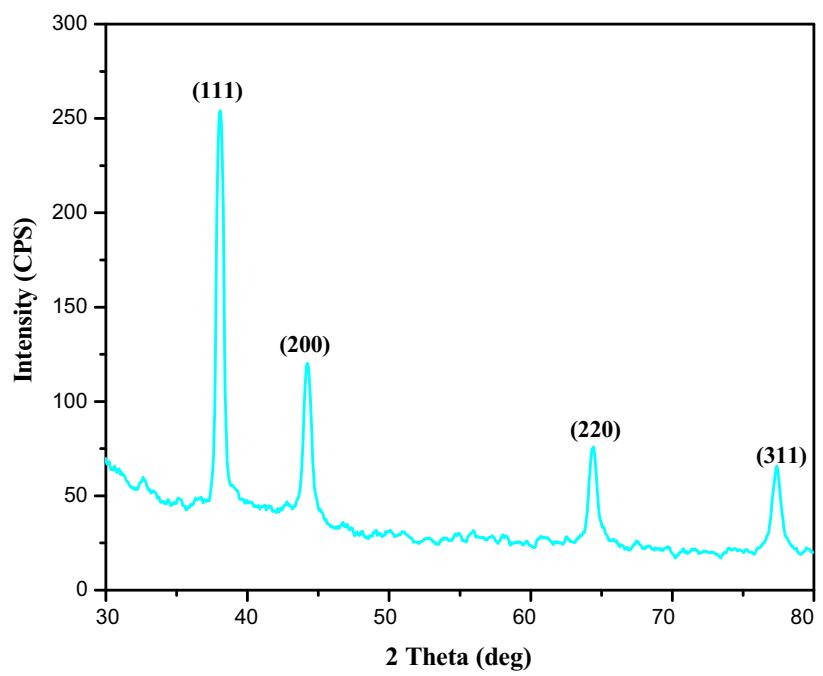

Fig. 3 XRD patterns of silver nanoparticles synthesized after $120 \mathrm{~h}$ of incubation 

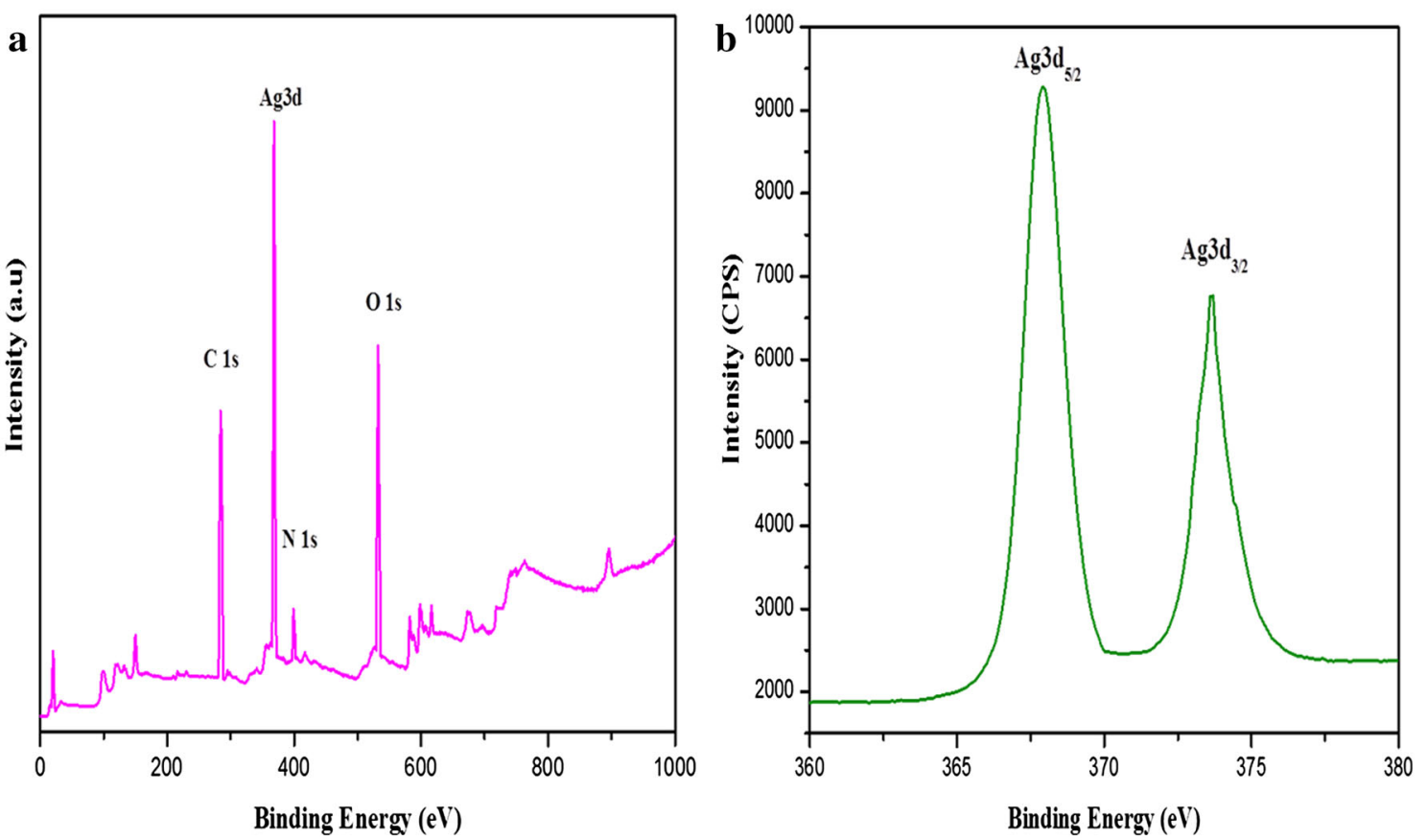

Fig. 4 High resolution XPS spectra of AgNPs showing, a survey scan and b Ag 3d

(Jeona and Kang 2008; Carroll et al. 2011). From the spectrum of $\mathrm{Ag} 3 \mathrm{~d}$ (Fig. 4b), the binding energies of $\mathrm{Ag}$ $3 \mathrm{~d}_{5 / 2}$ and $\mathrm{Ag} 3 \mathrm{~d}_{3 / 2}$ are found to be at 368 and $374 \mathrm{eV}$, respectively (Sumesh et al. 2011; Lai et al. 2010). Therefore, it is concluded that the proteins were responsible for the bio-reduction of $\mathrm{AgNO}_{3}$ into $\mathrm{Ag}$ nanoparticles.

\section{Functional group analysis}

The functional groups of $N$. nucifera responsible for the bio-reduction of $\mathrm{AgNO}_{3}$ into $\mathrm{Ag}$ nanoparticles can be explained from FT-IR analysis. The IR spectra of $N$. nucifera extract and $\mathrm{Ag}$ nanoparticles stabilized by the extract are shown in Fig. 5. For the leaf extract, FT-IR shows the major absorption peaks around 3361, 2922, 2360, 1647, $1540,1242,1058$, and $667 \mathrm{~cm}^{-1}$. The broad absorption band observed around $3361 \mathrm{~cm}^{-1}$ is the characteristic band of hydrogen-bonded NH groups. The absorption band positioned at $2922 \mathrm{~cm}^{-1}$ could be assigned to the $\mathrm{C}-\mathrm{H}$ stretching vibration of methyl, methylene, and methoxy groups (Feng et al. 2009). The appearance of peak at around $1647 \mathrm{~cm}^{-1}$ indicates the $\mathrm{C}=\mathrm{O}$ stretching of amide $\mathrm{I}$ bands of peptide linkage (Jeona and Kang 2008). The peaks at 1540 and $1242 \mathrm{~cm}^{-1}$ are the stretching vibration of $\mathrm{N}-\mathrm{H}$ groups and the bending vibration of $\mathrm{C}-\mathrm{N}$ groups, amide II and III bands, in the proteins (Carroll et al. 2011). The broad absorption positioned at $1058 \mathrm{~cm}^{-1}$ reveals the presence of aliphatic amides (Bouropoulos et al. 2001). The absorption band positioned at $667 \mathrm{~cm}^{-1}$ is due to the

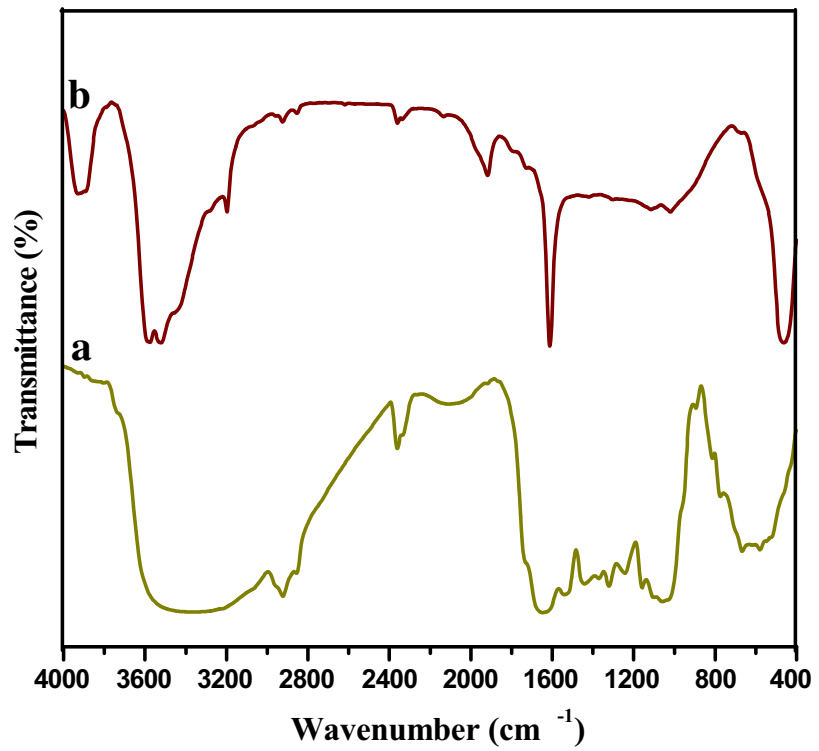

Fig. 5 FT-IR spectra of $a N$. nucifer $a$ extract and $b$ silver nanoparticles (AgNPs)

plane bending vibration of $\mathrm{N}-\mathrm{H}$ groups in the proteins (Shikuo et al. 2007). A similar kind of IR bands was observed for Ag nanoparticles with minor shift in these absorption bands. The minor shift may be due to the interaction of leaf extract with AgNPs which changed the original transmittance level of the extract. From the FT-IR spectra, it is concluded that the proteins are responsible for 
Fig. 6 FE-TEM images of synthesized silver nanoparticles using extract of $N$. nucifera
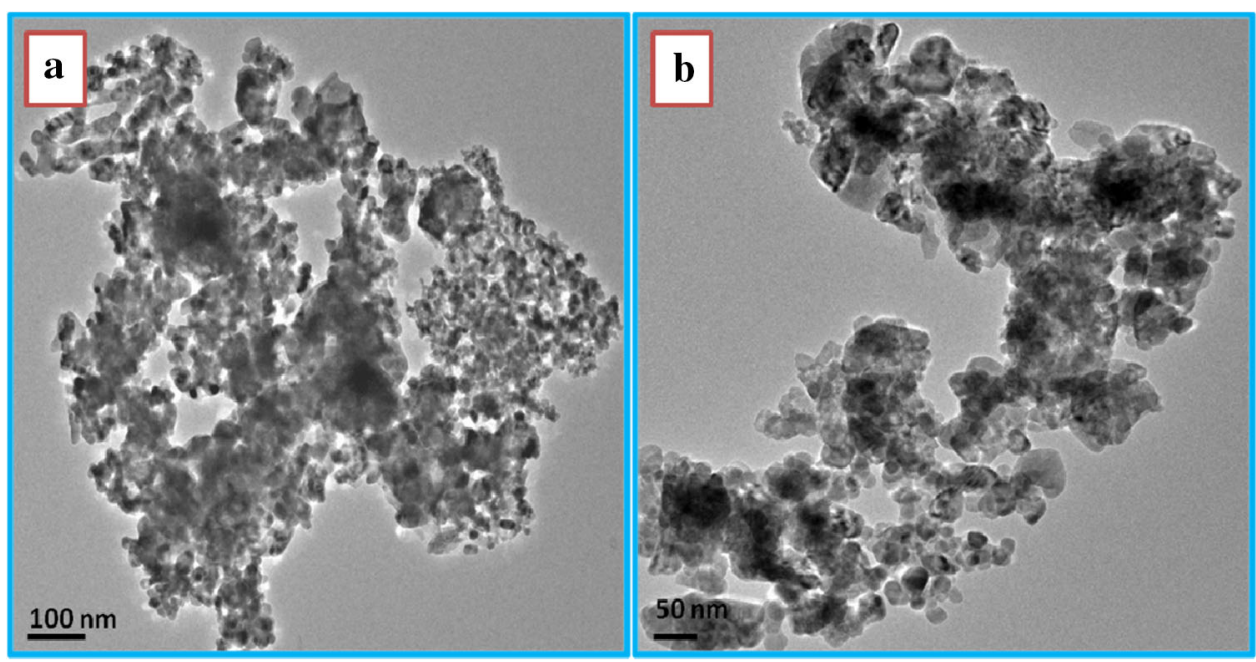

stabilizing the silver nanoparticles synthesized by the leaf extract of $N$. nucifera.

\section{Morphology and particle size}

The morphology and size of the synthesized AgNPs were analyzed by FE-TEM. The FE-TEM image of AgNPs synthesized after $120 \mathrm{~h}$ of incubation is shown in Fig. 6. The figure exhibited the morphology of the particles being spherical with sizes in the range of $30-40 \mathrm{~nm}$. To confirm the size of the Ag NPs, DLS measurement was recorded. Figure 7 shows the DLS histogram of the AgNPs obtained after $120 \mathrm{~h}$ of incubation. The average size of the particles as predicted from the histogram is $35 \mathrm{~nm}$. The obtained size is almost consistent with the result of FE-TEM.

\section{Antimicrobial activity}

The antimicrobial susceptibility of the synthesized Ag nanoparticles was investigated against the Gram-positive bacteria B.subtilis and gram-negative E.coli, S.typhi, and V.cholerae through disc diffusion method. Figure 8 illustrates the antibacterial activity of AgNPs and the positive control (Ampicillin) against the pathogens subjected for analysis. The diameter of each zone of inhibition was measured and the results are given in Table 1. The results indicate that the synthesized silver nanoparticles showed a considerable antimicrobial activity for all the pathogens studied; however, the highest zone of inhibition was recorded for B. subtilis $(16 \mathrm{~mm})$. The difference in antimicrobial activity between Gram-positive and Gram-negative could be due to their difference in membrane structure. The Gram-positive bacteria have a thick peptidoglycan layer, whereas, peptidoglycan layer in the Gram-negative bacteria is thinner but surrounded by a lipid layer outside (Gogoi et al. 2015). In the antimicrobial activity, initially AgNPs attach to the surface of the

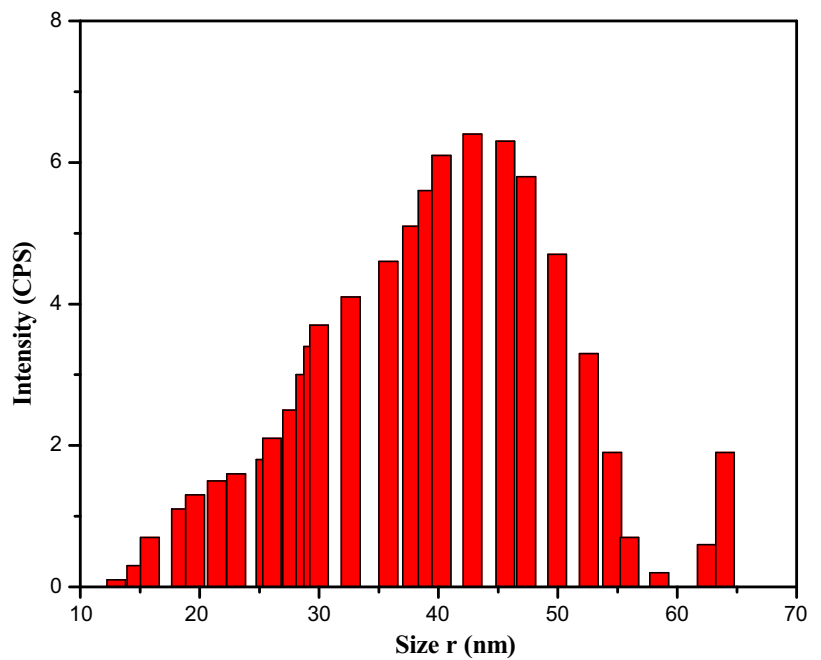

Fig. 7 DLS histogram of AgNPs size distribution

bacterial cell membrane and then penetrate into the bacteria. After penetration, they inactivate the enzymes of the microbes, generating hydrogen peroxide and causing bacterial cell death. The antibacterial properties of these green-synthesized AgNPs suggest their usage in medical devices as an antimicrobial coater.

\section{Conclusion}

In conclusion, a novel synthesis of silver nanoparticles through bio-reduction of silver nitrate using aqueous leaf extract of $N$. nucifera was demonstrated. The formation of AgNPs was confirmed by the presence of surface plasma resonance at $410 \mathrm{~nm}$. The crystalline nature of the synthesized product was confirmed by the diffraction results. FT-IR and XPS results suggest that proteins present in the extract were largely responsible for the bio-reduction of the silver nitrate into silver nanoparticles. The morphology of

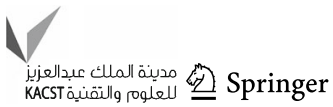


Fig. 8 Antibacterial activity of synthesized silver nanoparticles against a Escherichia coli, b Bacillus subtilis, c Salmonella typhi, and d Vibrio cholerae
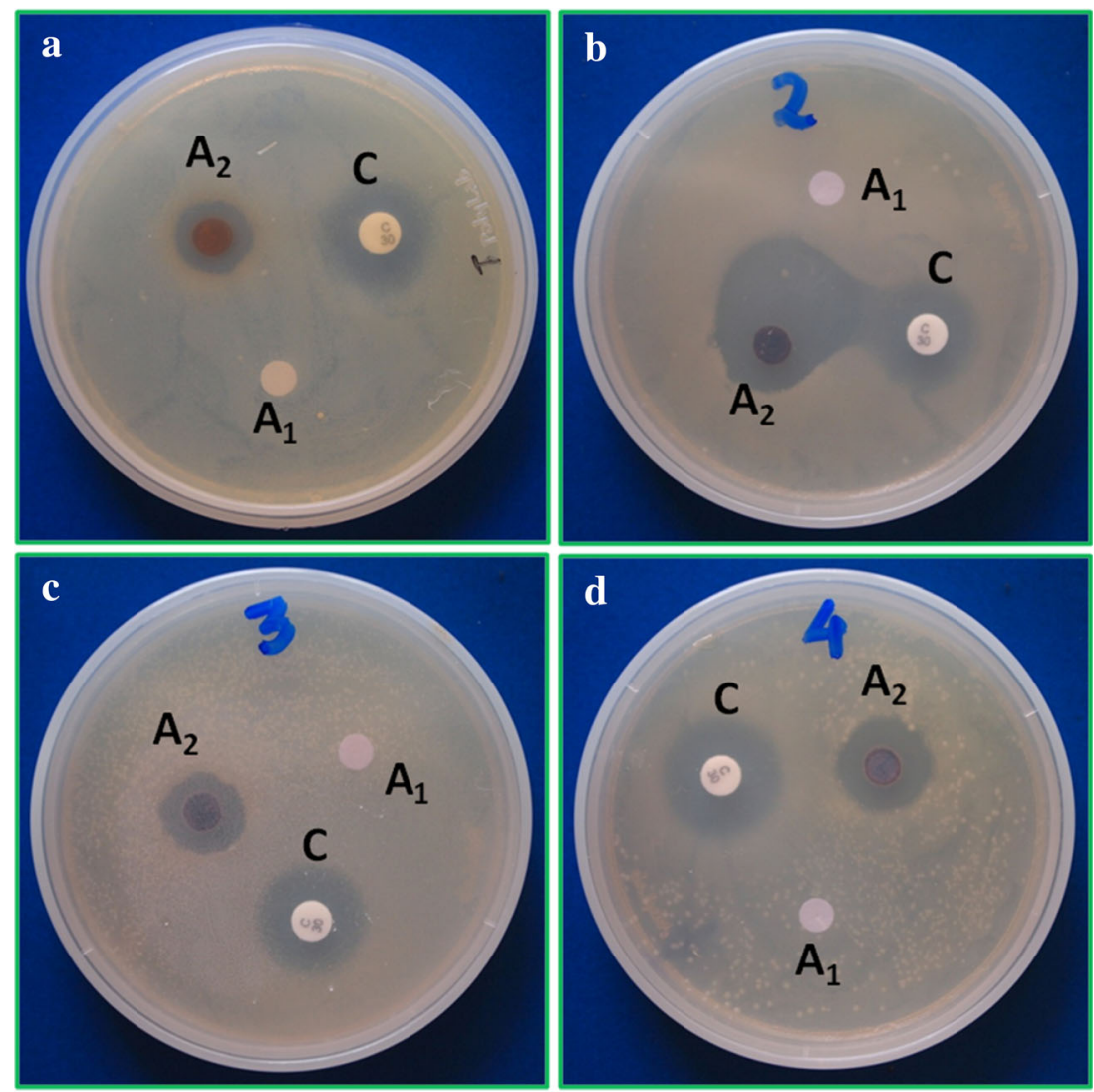

C-Positive control, $\mathrm{A}_{1}$-Negative control $\left(\mathrm{AgNO}_{3}\right), \mathrm{A}_{2}$ - $\mathrm{Ag} \mathrm{NPs}$
Table 1 Antibacterial activity of synthesized silver nanoparticles against some human pathogens

\begin{tabular}{lcl}
\hline Species & $\begin{array}{l}\text { Zone of inhibition } \\
\text { in mm for AgNPs }\left(\mathrm{A}_{2}\right)\end{array}$ & $\begin{array}{l}\text { Zone of inhibition in mm } \\
\text { for positive control }(\mathrm{C})\end{array}$ \\
\hline E. coli & 4 & 7 \\
B. subtilis & 16 & 6 \\
S. typhi & 5 & 7 \\
V. cholerae & 5 & 8 \\
\hline
\end{tabular}

the particles analyzed by FE-TEM showed the presence of spherical particles with sizes in the range of 30-40 nm. The DLS histogram also suggests the mono-dispersed size distribution of the particles. The antimicrobial activity of the AgNPs exhibits potential inhibitory activity against the Gram-positive bacteria B. subtilis, despite their activity being moderate for all other pathogens studied. Hence, the $N$. nucifera leaf extract-mediated synthesis of AgNPs can be suggested as good therapeutic agents against human pathogens and also for the successful development of drug delivery in future.

Acknowledgments The authors wish to thank Dr. S. Barathan, Professor and Head, Department of Physics, Annamalai University, for providing necessary facilities to carry out this work. Authors cordially thank Dr. A. Sundaramanickam, Assistant Professor, CAS in Marine Biology, Faculty of Marine Sciences, Annamalai University, Parangipettai, Tamil Nadu, India for his stimulating discussions during the performance of this work.

Open Access This article is distributed under the terms of the Creative Commons Attribution 4.0 International License (http:// creativecommons.org/licenses/by/4.0/), which permits unrestricted use, distribution, and reproduction in any medium, provided you give appropriate credit to the original author(s) and the source, provide a link to the Creative Commons license, and indicate if changes were made.

\section{References}

Abdel-Aziz MS, Shaheen MS, El-Nekeety AA, Abdel-Wahhab MA (2014) Antioxidant and antibacterial activity of silver nanoparticles biosynthesized using Chenopodium murale leaf extract. J Saudi Chem Soc 18:356-363

Alarcon EI, Udekwu K, Skog M, Pacioni NL, Stamplecoskie KG, González-Béjar M, Polisetti N, W A, Richter-Dahlfors Agneta, Griffith M, Scaiano JC (2012) The biocompatibility and antibacterial properties of collagen-stabilized, photochemically prepared silver nanoparticles. Biomaterials 33:4947-4956

Alt V, Bechert T, Steinrucke P, Wagener M, Seidel P, Dingeldein E, Domann E, Schnettler R (2004) An in vitro assessment of the antibacterial properties and cytotoxicity of nanoparticulate silver bone cement. Biomaterials 25:4383-4391 
Binupriya AR, Sathishkumar M, Vijayaraghavan K, Yun SI (2010) Bioreduction of trivalent aurum to nano-crystalline gold particles by active and inactive cells and cell-free extract of Aspergillus oryzae var. viridis. J Hazard Mater 177:539-545

Bo L, Yang W, Chen M, Gao J, Xue Q (2009) A simple and 'green' synthesis of polymer-based silver colloids and their antibacterial properties. Chem Biodivers 6:111-116

Bouropoulos N, Weiner S, Addadi L (2001) Calcium oxalate crystals in tomato and tobacco plants: morphology and in vitro interactions of crystal-associated macromolecules. Chem Eur J 7:1881-1888

Carroll KJ, Reveles JU, Shultz MD, Khanna SN, Carpenter EE (2011) Preparation of elemental $\mathrm{Cu}$ and $\mathrm{Ni}$ nanoparticles by the polyol method: an experimental and theoretical approach. J Phys Chem C 115:2656

Chou WL, Yu DG, Yang MC (2005) The preparation and characterization of silver-loading cellulose acetate hollow fiber membrane for water treatment. Polym Adv Technol 16:600-607

Feng N, Guo X, Liang S (2009) Adsorption study of $\mathrm{Cu}(\mathrm{II})$ by chemically modified orange peels. J Hazard Mater 164:1286-1292

Gogoi N, Babu PJ, Mahanta C, Bora U (2015) Green synthesis and characterization of silver nanoparticles using alcoholic flower extract of Nyctanthes arbortristis and in vitro investigation of their antibacterial and cytotoxic activities. Mater Sci Eng, C 46:463-469

Guidelli EJ, Ramos AP, Zaniquelli MED, Baffa O (2011) Green synthesis of colloidal silver nanoparticles using natural rubber latex extracted from Hevea brasiliensis. Acta Part A 82:140-145

Jeona MK, Kang M (2008) Synthesis and characterization of indiumtin-oxide particles prepared using sol-gel and solvothermal methods and their conductivities after fixation on polyethyleneterephthalate films. Mater Lett 62:676-682

Jeong SH, Yeo SY, Yi SC (2005) The effect of filler particle size on the antibacterial properties of compounded polymer/silver fibers. J Mater Sci 40:5407-5411

Jin M, Zhang XT, Nishimoto S, Liu ZY, Tryk DA, Emeline AV, Murakami T, Fujishima A (2007) Light-stimulated composition conversion in $\mathrm{TiO}_{2}$-based nanofibers. J Phys Chem C 8:658-665

Karting T, Still F, Reinhaler F (1991) Antimicrobial activity of the essential oil of young pine shoots (Picea abies L.). J Ethnopharmacol 35:155-157

Kouvaris P, Delimitis A, Zaspalis V, Papadopoulos D, Tsipas SA, Michailidis N (2012) Green synthesis and characterization of silver nanoparticles produced using Arbutus Unedo leaf extract. Mater Lett 76:18-20

Lai Y, Zhang H, Xie K, Gong D, Tang Y, Sun L, Lin C, Chen Z (2010) Fabrication of uniform $\mathrm{Ag} / \mathrm{TiO}_{2}$ nanotube array structures with enhanced photoelectrochemical performance. New J Chem 34:1335-1340

Lee HY, Park HK, Lee YM, Kim K, Park SB (2007) Comparative study on bactericidal effect of silver nanoparticles, synthesized using green technology, in combination with antibiotics on Salmonella typhi. Chem Commun 28:2959-2961

Li S, Shen Y, Xie A, Yu X, Qiu L, Zhang L, Zhang Q (2007) Green synthesis of silver nanoparticles using Capsicum annuит $\mathrm{L}$. extract. Green Chem 9:852-858
Nino-Martinez N, Martinez-Castanon GA, Aragon-Pina A, MartinezGutierrez F, Martinez Mendoza JR, Ruiz F (2008) Characterization of silver nanoparticles synthesized on titanium dioxide fine particles. Nanotechnology 19(6):065711/1-065711/8

Panacek AL, Kivtek L, Prucek R, Milan K, Vecerova R, Pizurova N (2006) Silver colloid nanoparticles: synthesis, characterization, and their antibacterial activity. J Phys Chem B 110:16248-16253

Panácek A, Kolár M, Vecerová R, Prucek R, Soukupová J, Krystof V, Hamal P, Zboril R, Kvítek L (2009) Antifungal activity of silver nanoparticles against Candida spp. Biomaterials 30:6333-6340

Prabhu D, Arulvasu C, Babu G, Manikandan R, Srinivasan P (2013) Biologically synthesized green silver nanoparticles from leaf extract of Vitexnegundo L. induce growth-inhibitory effect on human colon cancer cell line HCT15 Process. Biochemistry 48:317-324

Prucek R, Tuček J, Kilianová M, Panáček A, Kvítek L, Filip J, Kolář M, Tománková K, Zbořil R (2011) The targeted antibacterial and antifungal properties of magnetic nanocomposite of iron oxide and silver nanoparticles. Biomaterials 32:4704-4713

Rastogi L, Arunachalam J (2011) Sunlight based irradiation strategy for rapid green synthesis of highly stable silver nanoparticles using aqueous garlic (Allium sativum) extract and their antibacterial potential. Mater Chem Phys 129:558-563

Russel AD, Hugo WB (1994) Antimicrobial activity and action of silver. Prog Med Chem 31:351-370

Salem WM, Haridy M, Sayed WF, Hassan NH (2014) Antibacterial activity of silver nanoparticles synthesized from latex and leaf extract of Ficus sycomorus. Ind Crops Prod 62:228-234

Shanmugam N, Rajkamal P, Cholan S, Kannadasan N, Sathishkumar K, Viruthagiri G, Sundaramanickam A (2014) Biosynthesis of silver nanoparticles from the marine seaweed Sargassum wightii and their antibacterial activity against some human pathogens. Appl Nanosci. doi:10.1007/s13204-013-0271-4

Sharma J, Chaki NK, Mandale AB, Pasricha R, Vijayamohanan K (2004) Controlled interlinking of $\mathrm{Au}$ and $\mathrm{Ag}$ nanoclusters using 4-aminothiophenol as molecular interconnects. J Colloid Interface Sci 272:145-152

Sulaiman GM, Mohammed WH, Marzoog TR, Al-Amiery AAA, Kadhum AAH, Mohamad AB (2013) Green synthesis, antimicrobial and cytotoxic effects of silver nanoparticles using Eucalyptus chapmaniana leaves extract. Asian Pac J Trop Biomed 3:58-63

Sumesh E, Bootharaju MS, Pradeep AT (2011) A practical silver nanoparticle-based adsorbent for the removal of $\mathrm{Hg}^{2+}$ from water. J Hazard Mater 189:450

Tomsic B, Simoncic B, Orel B, Cerne L, Tavcer P, Zorko M, Jerman A (2008) Sol-gel coating of cellulose fibers with antimicrobial and repellent properties. Sol-Gel Sci Technol 47:44-57

Vijayakumar R, Devi V, Adavallan K, Saranya D (2011) Green synthesis and characterization of gold nanoparticles using extract of anti-tumor potent Crocus sativus. Phys E 44:665

Yilmaz M, Turkdemir H, Akif Kilic M, Bayram E, Cicek A, Mete A, Ulug B (2011) Biosynthesis of silver nanoparticles using leaves of Stevia rebaudiana. Mater Chem Phys 130:1195-1202 